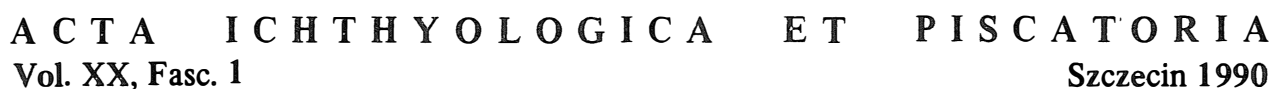

Tomasz HEESE

Systematics

\title{
CRANIAL OSTEOLOGY OF THE WHITEFISH, COREGONUS LAVARETUS (L., 1758) FROM THE POMERANIAN BAY
}

\section{OSTOLOGIA CZASZKI SIEI, COREGONUS LAVARETUS (L., 1758) ZATOKI POMORSKIEJ}

\author{
Department of Environmental Biology \\ and Chemistry, \\ Technical University, Koszalin
}

\begin{abstract}
The Pomeranian Bay whitefish stock comprises two plastic forms: typical and humpback. Detailed morphological comparisons revealed significant differences between the two form with respect to certain characters. Cranial osteology of 60 individuals showed morphology of the dentary to be different in the two forms, the numerical expression of the differences showing their statistical significance. Values for the remaining characteristics analysed (a total of 21) were similar in the two forms. In addition, some cranial elements were found to be extremely variable. Measurement taken on few skulls only are, however, of a limited systematic value.
\end{abstract}

\section{INTRODUCTION}

Systematics of the genus Coregonus and the number of species the genus contains are not firmly established yet. Both Dorofejeva et al. (1980) and Resetnikov $(1980,1988)$ list about 20 species. A lucid species classification is usually based on morphological criteria, including the anatomical ones. In the case of Coregonus, however, the characters are not so distinct. Frequently, the gill raker count was used as the most important diagnostic character, as e.g. in Svärdson (1957) who regarded the character to be genetically controlled. Later works (Gąsowska, 1960; Behnke, 1972) ceased to treat the gill raker count as a constant character, and so did Svärdson (1979) himself. In her preliminary revision of the genus Coregonus, Gąsowska (1.960) attempted to prove a 
considerable utility of shapes and proportions of the maxilla and supramaxilla. She treated the gill raker count as a subordinate feature applicable in the intraspecific systematics. In her systematics of the whitefish from the Soviet Union, Saposnikova (1968) additionally considered a number of plastic cranial characters.

The Pomeranian Bay is inhabited by ammigratory whitefish population spawning in the Szczecin Lagoon. The population consists of two plastic $x_{1}^{0}$ orms: typical and humpback (Fig, 1 and 2). The forms differ in certain plastic characters and, to some degree, in the vertebral count (Heese, 1987).

Osteologic studies on the Pomeranian Bay whitefish skulls are aimed at comparing the two forms in terms of differences between the cranial bones and at determining the

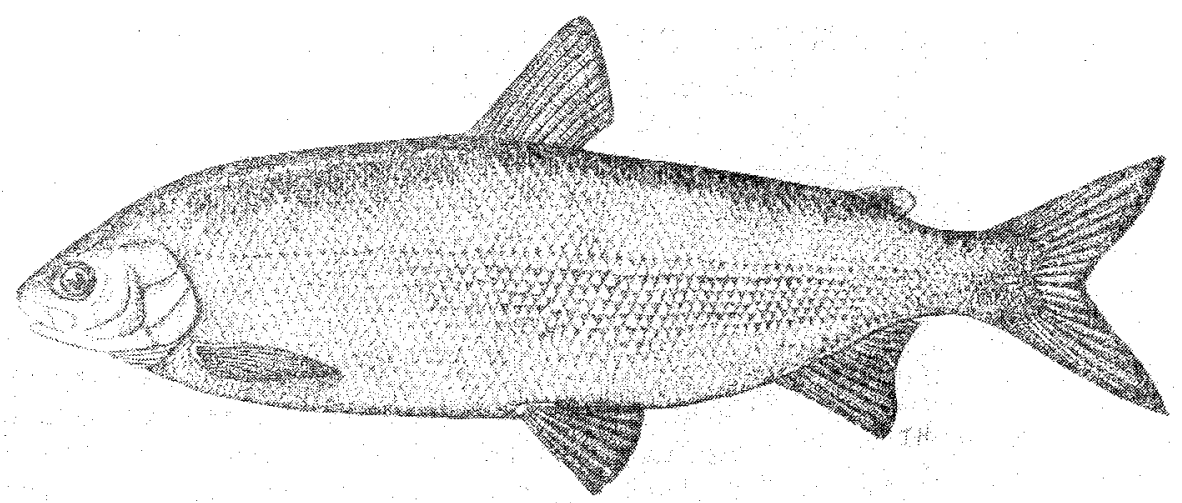

Fig. 1. The Pomeranian Bay whitefish: ty pical form

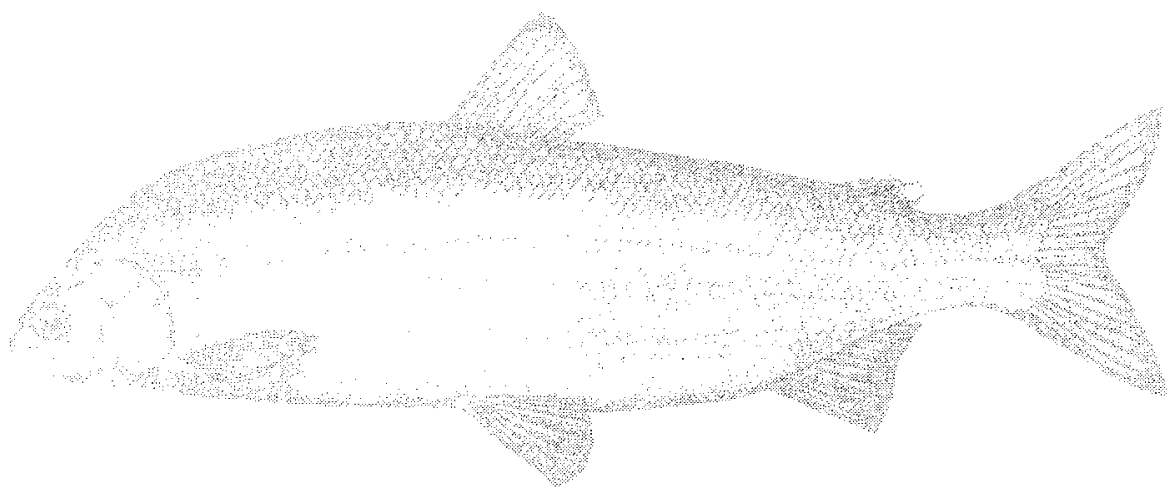

Fig. 2. The Pomeranian Bay whitefish: humpback form 
extert of variability of the characters analysed. The low number of osteological papers based on appropriate sample sizes makes comparison of the present results with the literature data very difficult.

\section{MATERIALS AND METHODS}

The whitefish to be studied were caught by commercial fisherman in November 1984 in the Pomeranian Bay off the mouth of the river Swina which forms a connection between the Szczecin Lagoon and the Bay. The Pomeranian Pay $^{2}$ covers an inshore area between the coast and the 20-m depth contour and between Cape Arkona (Island of Rügen) and the Gąski lightohouse (Fig. 3).

A total of 60 whitefish individuals were examined, 30 belonging to the typical and 30 to the humpback form. Skull skin and muscles were removed by gradually treating them with hot water. Cranial measurements (Fig. 4) were taken as recommended by Šapošnikova (1968). Additionally, certain elements of the maxilla, supramaxilla, mesethmoid, posttemporal, and dentary were measured (Fig. 5). In the case of paired

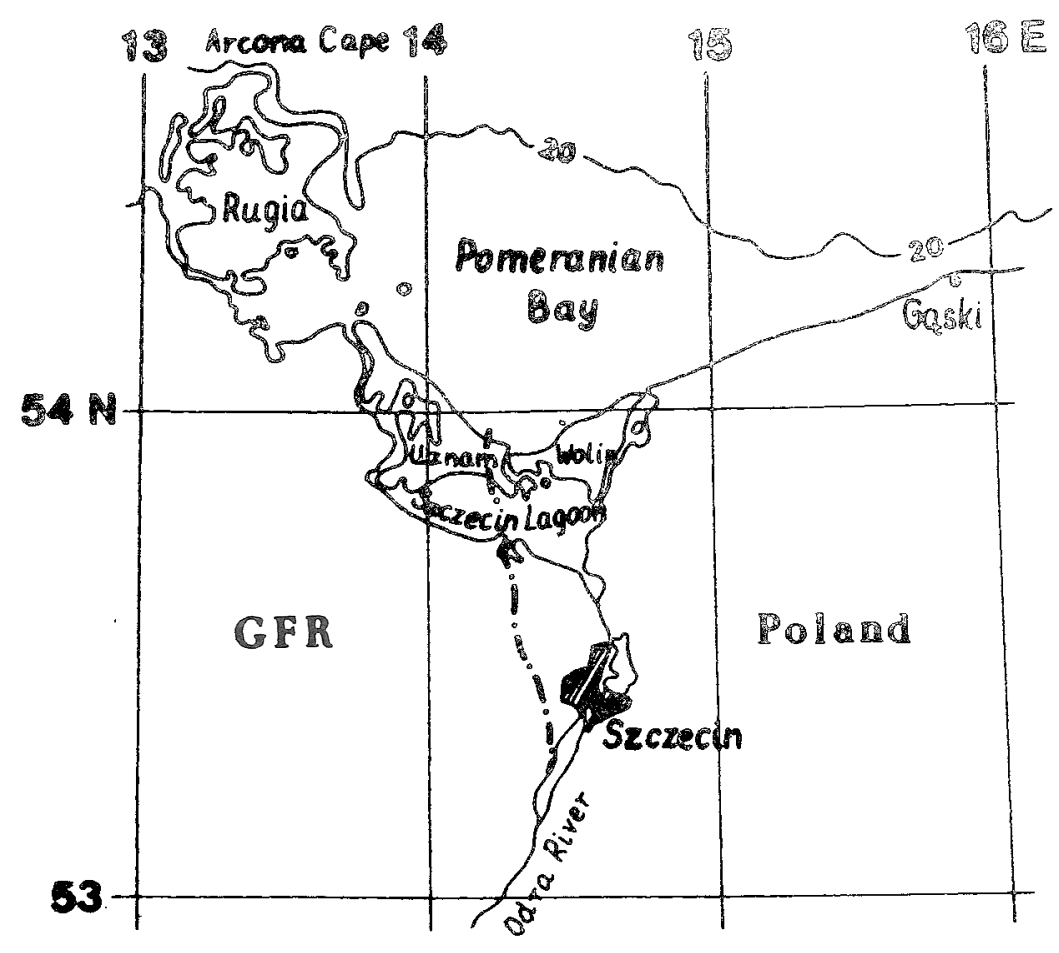

Fig. 3. Map of the Pomeranian Bay 

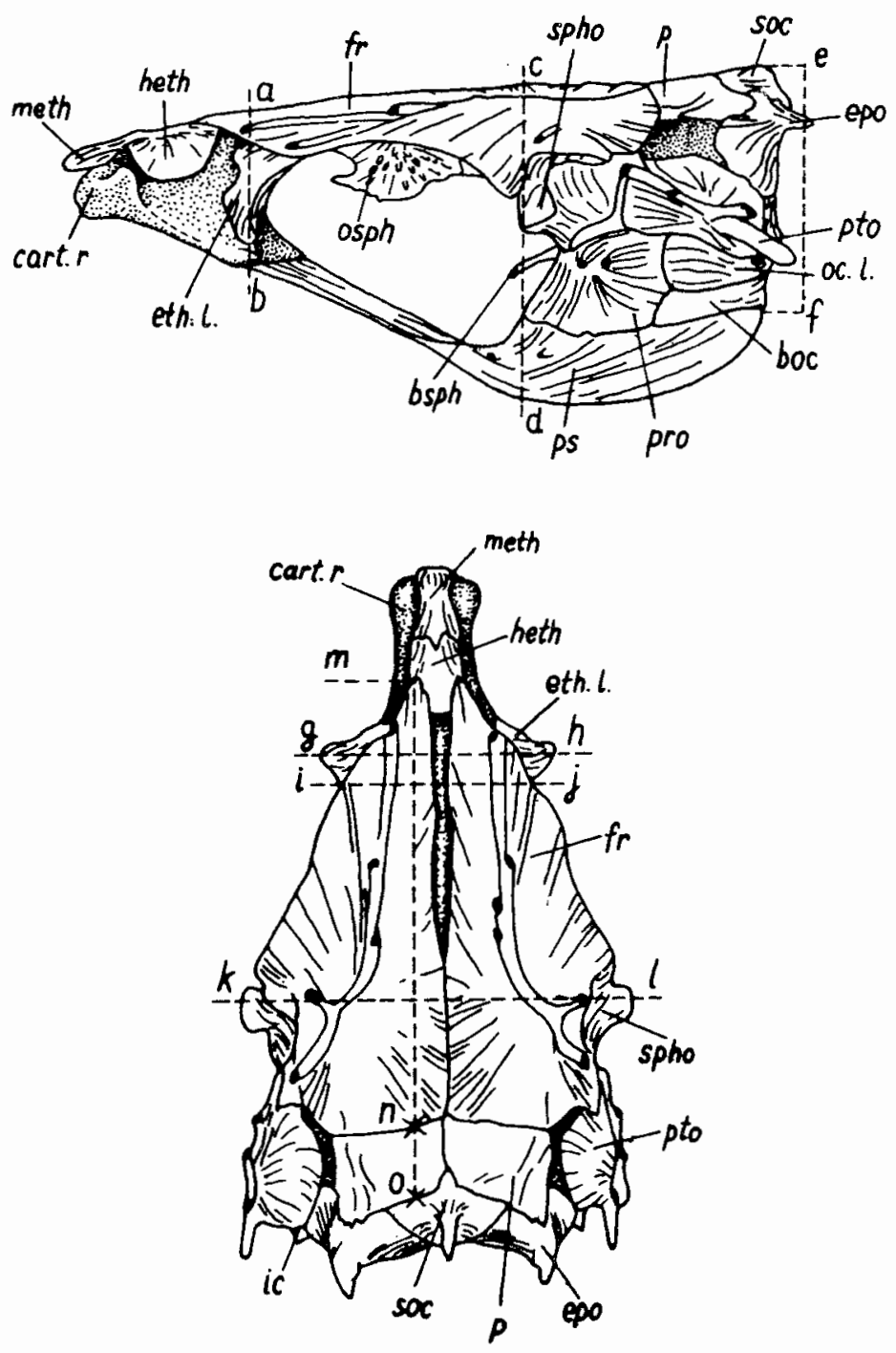

Fig. 4. Diagram of cranial measurements.

$a b=$ height at lateral ethmoid level; $c d=$ height at prootic anterior margin level; ef= height from base of basioccipital to end of supraoccipital; $\mathrm{gh}=$ wid th at lateral e thmoid level;

$\mathrm{ij}=$ width behind la tera ethmoid; $\mathrm{kl}=$ wid th at sphenotic level;

$\mathrm{mn}=$ length of frontal; no $=$ length of parietal. Cranial bones denoted as: boc $=$ basioccipital; bsph $=$ basiphenoid $;$ cart.r. $=$ rostral cartilage $;$ epo $=$ epiotic;

eth.l. = lateral etmoid; fr $=$ frontal; heth = hypethmoid; ic = intercalar;

meth = mesethmoid; oc.l. = lateral occipital; osph = orbitosphenoid; $p=$ parietal; pro $=$ prootic; $p s=$ parasphenoid $;$ pto $=$ pterotic; $s o c=$ supraoccipital $;$ spho $=$ sphenotic 


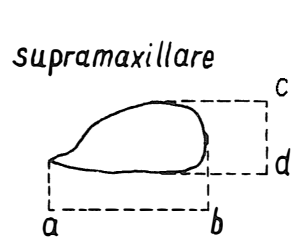

mesethmoideum

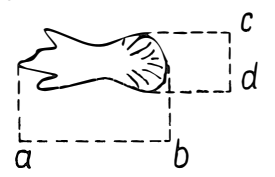

posttemporale
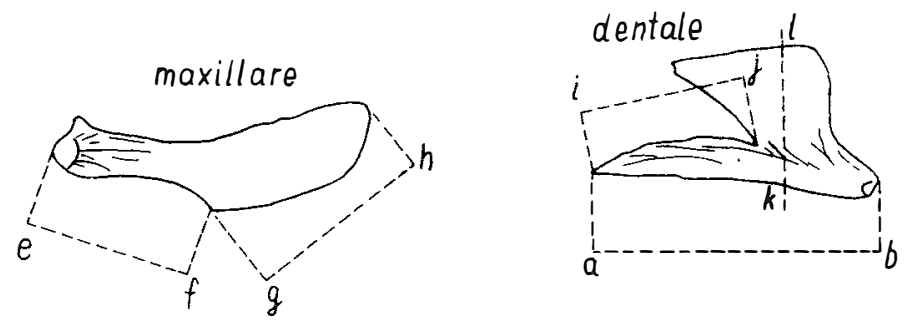

Fig. 5. Diagram of measurements on selected bones $a b=$ length $; c d=$ width; ef = length of anterior part of maxilla; $g h=$ length of posterior part of maxilla; $\mathrm{ij}=$ distal length of dentary; $\mathrm{kl}=$ height of dentary

bones, those in the right side of the skull were measured. All the measurements were made to $0.1 \mathrm{~mm}$.

Statistical treatment of data involved calculations of mean values (M), standard errors of the mean (m), standard deviations (S), and coefficients of variation (CV). The differences were tested for significance by means of Student's $t$ test. Confidence intervals were calculated to facilitate statistical inference.

\section{RESULTS}

Tables 1 and 2 summarise morphological cranial characteristics of the typical and humpback forms, respectively. Mean values for most characters are very similar in both forms. The perceptible difference appear in an index representing the dentary height expressed in per cent of the distal length of the bone. The index is $100.61 \%$ in the typical form, which means that the mean height of the dentary is almost equal to its distal length On the other hand, the respectively humpback index is $96.2 \%$. In other words, the humpback dentary is more caved in (Fig. 6). Detailed data are given in Table 3. The confidence interval for the difference at $\alpha=0.05$ is as follows:

$$
0.46<\mathrm{m}_{1}-\mathrm{m}_{2}<8.22
$$

where: $\mathrm{m}_{1}=\mathrm{m}$ of typical form

$\mathrm{m}_{2}=\mathrm{m}$ of humpback form. 
Cranial osteological characterisation of typical form of the whitefish

\begin{tabular}{|c|c|c|c|c|c|}
\hline Character & $\mathrm{n}$ & Range & $\mathrm{M} \pm \mathrm{m}$ & $S$ & $\mathrm{CV}$ \\
\hline Skull lemgth & 30 & $45.4-66.5$ & $54.09 \pm 0.95$ & 5.20 & 9.6 \\
\hline \multicolumn{6}{|c|}{ skull length $=100$} \\
\hline Width at lateral ethmoid level & 30 & $30.6-36.5$ & $32.71 \pm 0.29$ & 1.58 & 4.8 \\
\hline Width behind lateral etmoid & 30 & $23.6-29.2$ & $25.68 \pm 0.22$ & 1.21 & 4.7 \\
\hline Width at sphenotic level & 30 & $51.4-58.9$ & $54.49 \pm 0.32$ & 1.77 & 3.2 \\
\hline Height at lateral etmoid level & 30 & $23.3-28.7$ & $26.08 \pm 0.24$ & 1.30 & 5.0 \\
\hline Height at prootic anterior margin level & 30 & $41.3-46.6$ & $43.39 \pm 0.26$ & 1.45 & 3.3 \\
\hline $\begin{array}{l}\text { Height from base of basiocc. to end of } \\
\text { supraoccipital }\end{array}$ & 30 & $38.0-44.6$ & $40.03 \pm 0.31$ & 1.68 & 4.2 \\
\hline Length of frontal & 30 & $57.7-66.4$ & $63.21 \pm 0.39$ & 2.16 & 3.4 \\
\hline Length of parietal & 30 & $5.4-12.6$ & $9.16 \pm 0.31$ & 1.75 & 19.1 \\
\hline Length of maxilla & 30 & $40.4-50.5$ & $44.5 \pm 0.45$ & 2.49 & 5.6 \\
\hline Width of supram axilla & 30 & $7.2-10.0$ & $8.76 \pm 0.45$ & 0.89 & 10.2 \\
\hline Length of supramaxilla & 30 & $15.3-21.6$ & $19.23 \pm 0.30$ & 1.63 & 8.5 \\
\hline Width of mesethmoid & 30 & $3.1-8.1$ & $5.63 \pm 0.27$ & 1.47 & 26.1 \\
\hline Length of mesethmoid & 30 & $13.5-25.2$ & $18.30 \pm 0.47$ & 2.55 & 13.9 \\
\hline Width of posttemporal & 30 & $14.0-19.5$ & $16.38 \pm 0.27$ & 1.46 & 8.9 \\
\hline Length of posttemporal & 30 & $41.0-53.2$ & $47.95 \pm 0.57$ & 3.11 & 6.5 \\
\hline Length of dentary & 29 & $34.9:-44.3$ & $40.94 \pm 0.40$ & 2.11 & 5.2 \\
\hline Height of dentary & 29 & $20.7-25.2$ & $22.32 \pm 0.20$ & 1.04 & 4.7 \\
\hline \multicolumn{6}{|c|}{ Length of posterior part of maxilla $=100$} \\
\hline Length of anterior part of maxilla & 30 & $55.9-99.1$ & $79.20 \pm 1.85$ & 10.12 & 12.8 \\
\hline \multicolumn{6}{|c|}{ Length of supramaxilla $=100$} \\
\hline Width of supramaxilla & 30 & $33.9-54.4$ & $45.73 \pm 0.89$ & 4.90 & 10.7 \\
\hline \multicolumn{6}{|c|}{ Length of posttemporal $=100$} \\
\hline Width of posttemporal & 30 & $27.2-39.7$ & $34.42 \pm 0.65$ & 3.58 & 10.4 \\
\hline \multicolumn{6}{|c|}{ Length of dentary $=100$} \\
\hline $\begin{array}{l}\text { Distal length of dentary } \\
\text { Height of dentary }\end{array}$ & $\begin{array}{l}29 \\
29\end{array}$ & $\begin{array}{l}50.0-61.2 \\
51.4-61.3\end{array}$ & $\begin{array}{l}54.32 \pm 0.54 \\
54.61 \pm 0.55\end{array}$ & $\begin{array}{l}2.86 \\
2.91\end{array}$ & $\begin{array}{l}5.3 \\
5.3\end{array}$ \\
\hline \multicolumn{6}{|c|}{ Distal length of dentary $=100$} \\
\hline Height of dentary & 29 & $86.7-119.0$ & $100.61 \pm 1.37$ & 7.23 & 7.2 \\
\hline
\end{tabular}


Cranial osteological characterisation of humpback form of the whitefish

\begin{tabular}{|c|c|c|c|c|c|}
\hline Character & $\mathrm{n}$ & Range & $\mathrm{M} \pm \mathrm{m}$ & S & $\mathrm{CV}$ \\
\hline Skull length & 30 & $45.6-66.7$ & $56.11 \pm 1.02$ & 5.59 & 10.0 \\
\hline \multicolumn{6}{|c|}{ Skull length $=100$} \\
\hline Wid th at lateral etlmoid level & 30 & $29.5-37.1$ & $32.22 \pm 0.29$ & 1.61 & 5.0 \\
\hline Width behind lateral ethmoid & 30 & $23.9-28.0$ & $25.65 \pm 0.23$ & 1.26 & 4.9 \\
\hline Width at sphenotic level & 30 & $52.8-59.3$ & $54.99 \pm 0.35$ & 1.89 & 3.4 \\
\hline Height at lateral etmoid level & 30 & $24.2--28.5$ & $26.26 \pm 0.22$ & 1.21 & 4.6 \\
\hline Height at prootic anterior margin level & 30 & $40.8-47.2$ & $43.78 \pm 0.26$ & 1.45 & 3.3 \\
\hline $\begin{array}{l}\text { Height from base of basiocc. to end } \\
\text { of supraoccipital }\end{array}$ & 30 & $38.0-41.4$ & $39.76 \pm 0.22$ & 1.22 & 3.1 \\
\hline Length of frontal & 30 & $59.2-68.2$ & $63.95 \pm 0.33$ & 1.81 & 2.8 \\
\hline Length of parietal & 30 & $5.5-12.1$ & $8.64 \pm 0.30$ & 1.63 & 18.9 \\
\hline Length of maxilla & 30 & $40.8-49.4$ & $44.85 \pm 0.34$ & 1.84 & 4.1 \\
\hline Width of supramaxilla & 30 & $7.4-11.1$ & $8.71 \pm 0.16$ & 0.89 & 10.2 \\
\hline Length of supramaxilla & 30 & $17.1-21.3$ & $18.83 \pm 0.20$ & 1.11 & 5.9 \\
\hline Width of mesethmoid & 30 & $3.3-8.7$ & $5.63 \pm 0.29$ & 1.57 & 27.9 \\
\hline Length of mesethmoid & 30 & $13.7-20.8$ & $17.51 \pm 0.46$ & 2.54 & 14.5 \\
\hline Width of posttem poral & 30 & $14.3-19.7$ & $16.63 \pm 0.27$ & 1.46 & 8.8 \\
\hline Length of posttemporal & 30 & $42.1-52.9$ & $48.12 \pm 0.48$ & 2.64 & 5.5 \\
\hline Length of dentary & 30 & $37.9 \ldots 46.1$ & $41.85 \pm 0.34$ & 1.86 & 4.4 \\
\hline Height of dentary & 30 & $20.2-24.6$ & $22.40 \pm 0.22$ & 1.19 & 5.3 \\
\hline \multicolumn{6}{|c|}{ Length of posterior part of maxilla $=100$} \\
\hline Length of anterior part of maxilla & 30 & $66.9-93.0$ & $80.15 \pm 1.21$ & 6.65 & 8.3 \\
\hline \multicolumn{6}{|c|}{ Length of supramaxilla $=100$} \\
\hline Width of supramaxilla & 30 & $38.3-57.1$ & $46.45 \pm 0.93$ & 5.09 & 11.0 \\
\hline \multicolumn{6}{|c|}{ Length of posttemporal $=100$} \\
\hline Width of posttemporal & 30 & $29.1-40.7$ & $34.59 \pm 0.50$ & 2.75 & 8.0 \\
\hline \multicolumn{6}{|c|}{ Length of dentary $=100$} \\
\hline $\begin{array}{l}\text { Distal length of dentary } \\
\text { Heigth of dentary }\end{array}$ & $\begin{array}{l}30 \\
30\end{array}$ & $\begin{array}{l}50.6-61.9 \\
46.9-58.7\end{array}$ & $\begin{array}{l}55.61 \pm 0.50 \\
53.42 \pm 0.57\end{array}$ & $\begin{array}{l}2.74 \\
3.13\end{array}$ & $\begin{array}{l}4.9 \\
5.9\end{array}$ \\
\hline \multicolumn{6}{|c|}{ Distal length of dentary $=100$} \\
\hline Heigth of dentary & 30 & $86.0-116.8$ & $96.27 \pm 1.35$ & 7.40 & 7.7 \\
\hline
\end{tabular}




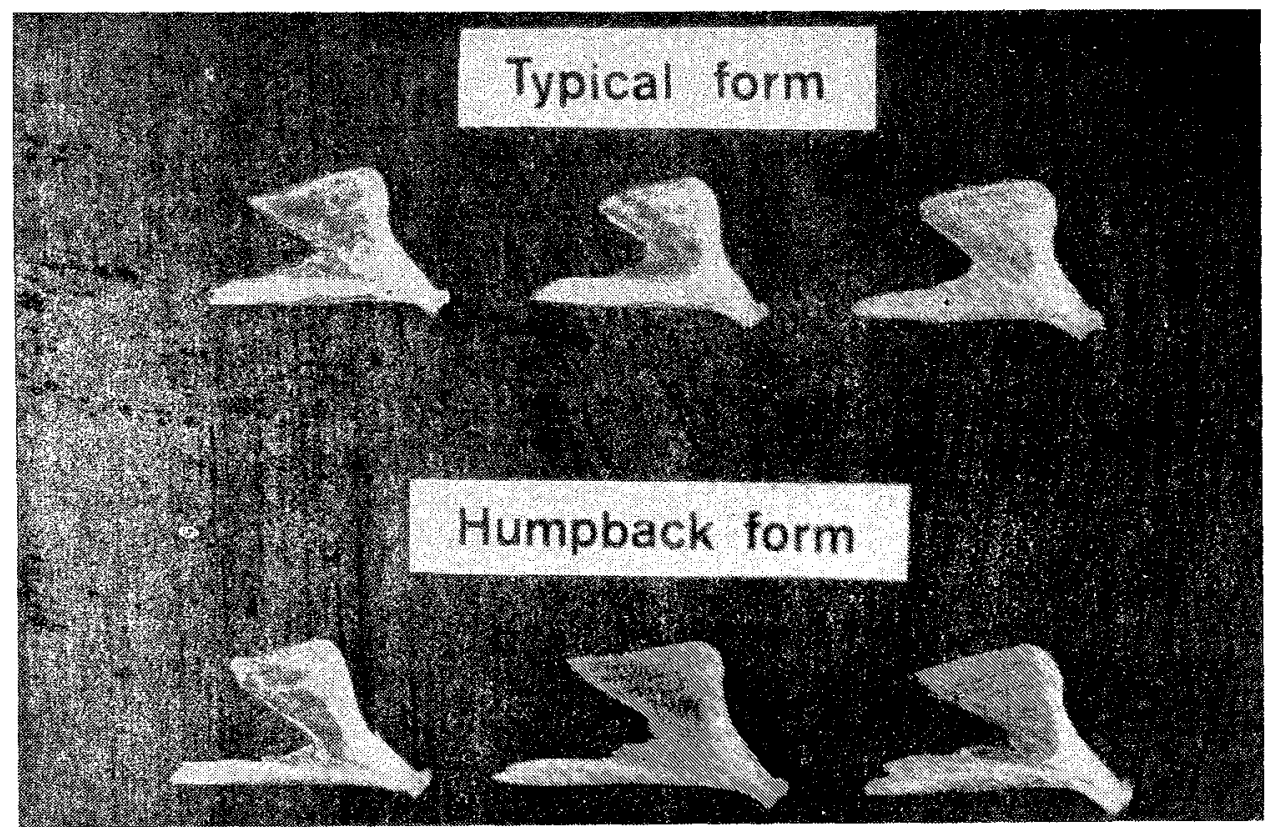

Fig. 6. Dentary in two plastic forms of the whitefish

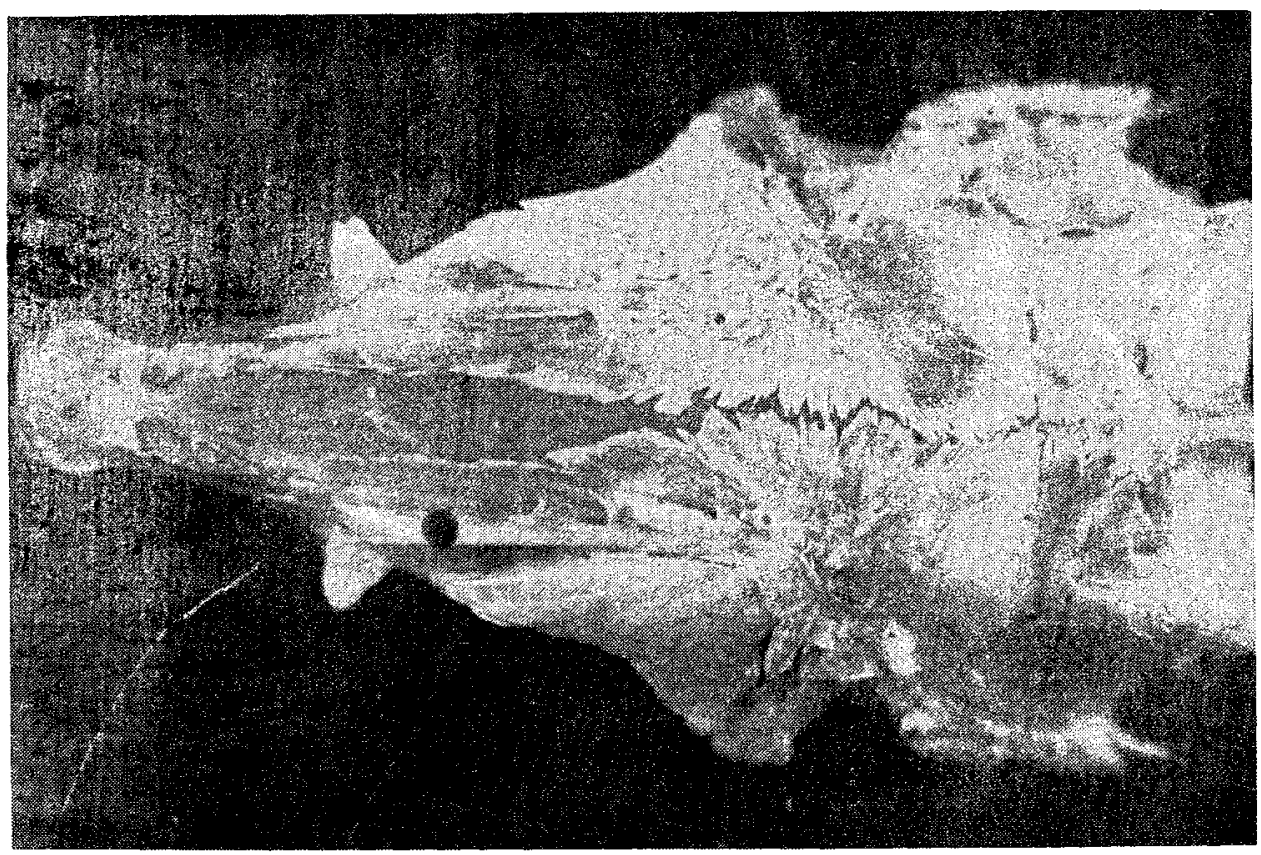

Fig. 7. Whitefish skull in dorsal view 


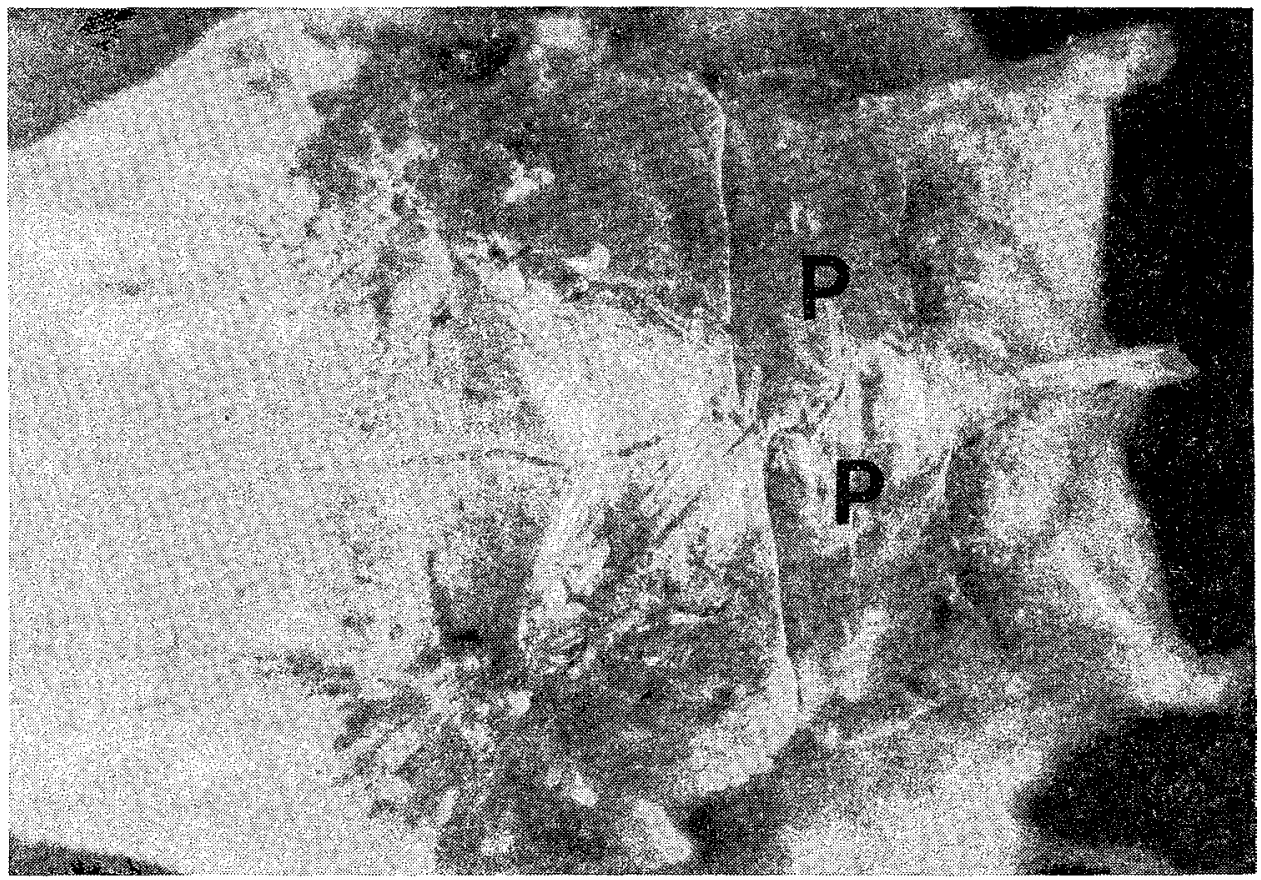

Fig. 8. Parietal bones (p) contacting along the entire length

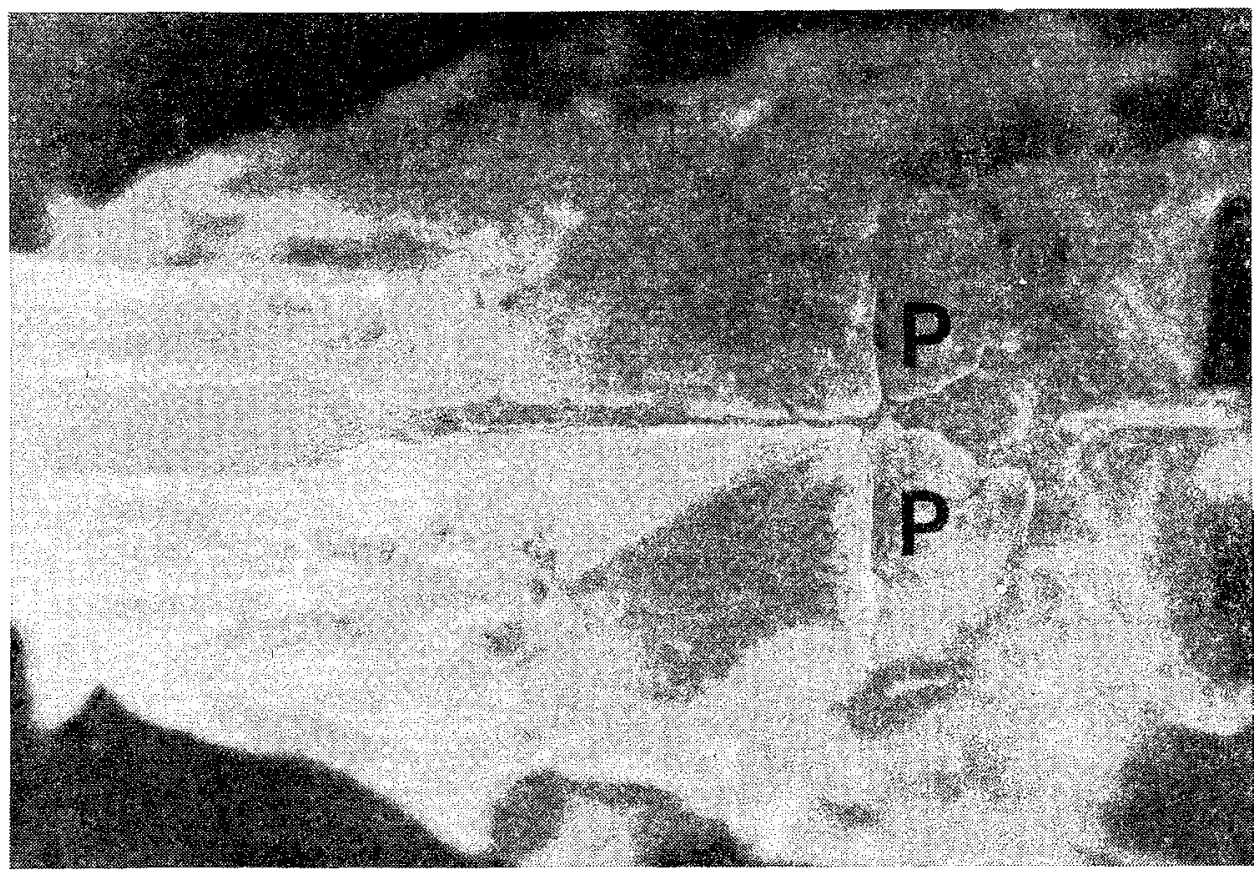

Fig. 9. Parie tal bones (p) partially separated 
Comparison of dentary proportions in typical and humpback forms, significantly different at $\alpha=0.05$

\begin{tabular}{|l|c|c|c|c|c|c|c|}
\hline Character & Form & Range & $\mathrm{M}$ & $\mathrm{F}^{\circ}$ & $\mathrm{F}_{0.05}$ & $\mathrm{i}^{0-}$ & $\mathrm{t}_{0.05}$ \\
\hline \multicolumn{7}{|c|}{ distal length of dentary = 100} \\
\hline $\begin{array}{l}\text { Height of } \\
\text { dentary }\end{array}$ & typical & $86.7-119.0$ & 100.61 & 1.04 & 1.85 & 2.24 & 2.00 \\
\cline { 2 - 7 } & humpback & $86.0-116.8$ & 96.27 & 1.04 & \\
\hline
\end{tabular}

Table 4

Arrangement of parietal bones in the whitefish forms studies

\begin{tabular}{|c|c|c|c|c|c|c|}
\hline \multirow{2}{*}{ Sample size } & \multicolumn{3}{|c|}{ Typical form } & \multicolumn{3}{c|}{ Humpback form } \\
\cline { 2 - 7 } & \multicolumn{3}{|c|}{ parietal arrangement } & \multicolumn{3}{c|}{ parietal arrangement } \\
\cline { 2 - 7 } & connected & $\begin{array}{c}\text { connected } \\
\text { partially }\end{array}$ & separated & connected & $\begin{array}{c}\text { connected } \\
\text { partially }\end{array}$ & separated \\
\hline$n$ & 4 & 11 & 15 & 4 & 12 & 14 \\
\hline$\%$ & 13.3 & 36.7 & 50.0 & 13.3 & 40.0 & 46.7 \\
\hline
\end{tabular}

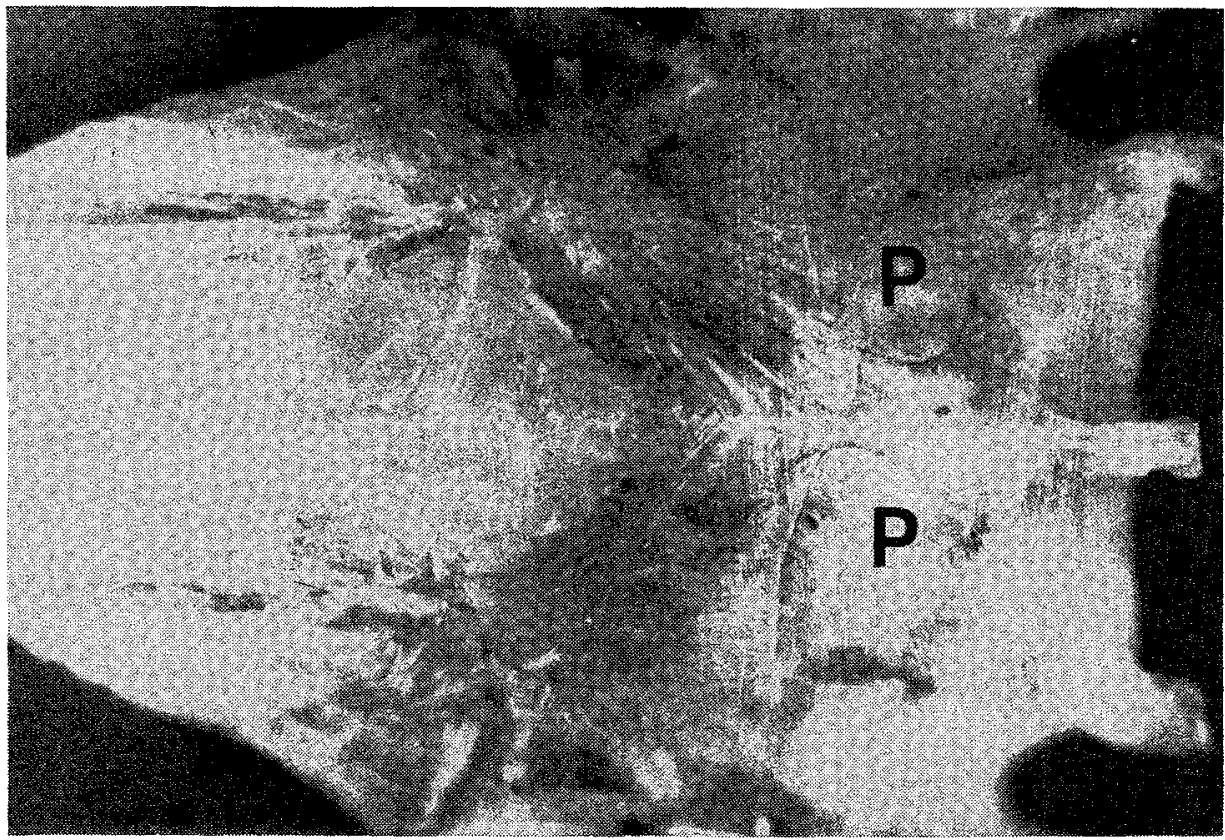

Fig. 10. Parietal bones (p) completely separated 
Thus the mean value for the typical form exceeds the humpback mean by at least 0.46 and by $8.22 \%$ at the most.

Fig. 7 shows a whitefish skull in dorsal view. As seen from Tables 1 and 2, the most variable characters $(C V \geqslant 10 \%)$ include length of the parietal, width of the supramaxilla, length and width of the mesethmoid, and proportions in the maxilla, supramaxilla, and posttemporal. The parietal bone organization proved very variable and can serve as a basis for dividing the skulls examined into three groups. The first group contains skulls having the parietal bones contacting each other along their whole length (Fig. 8); in the second group, the bones are partially separated (Fig. 9), the separation being complete in the third (Fig. 10). Each whitefish form contained skulls belonging to all three groups (Table 4), the third group being the commonest arrangement.

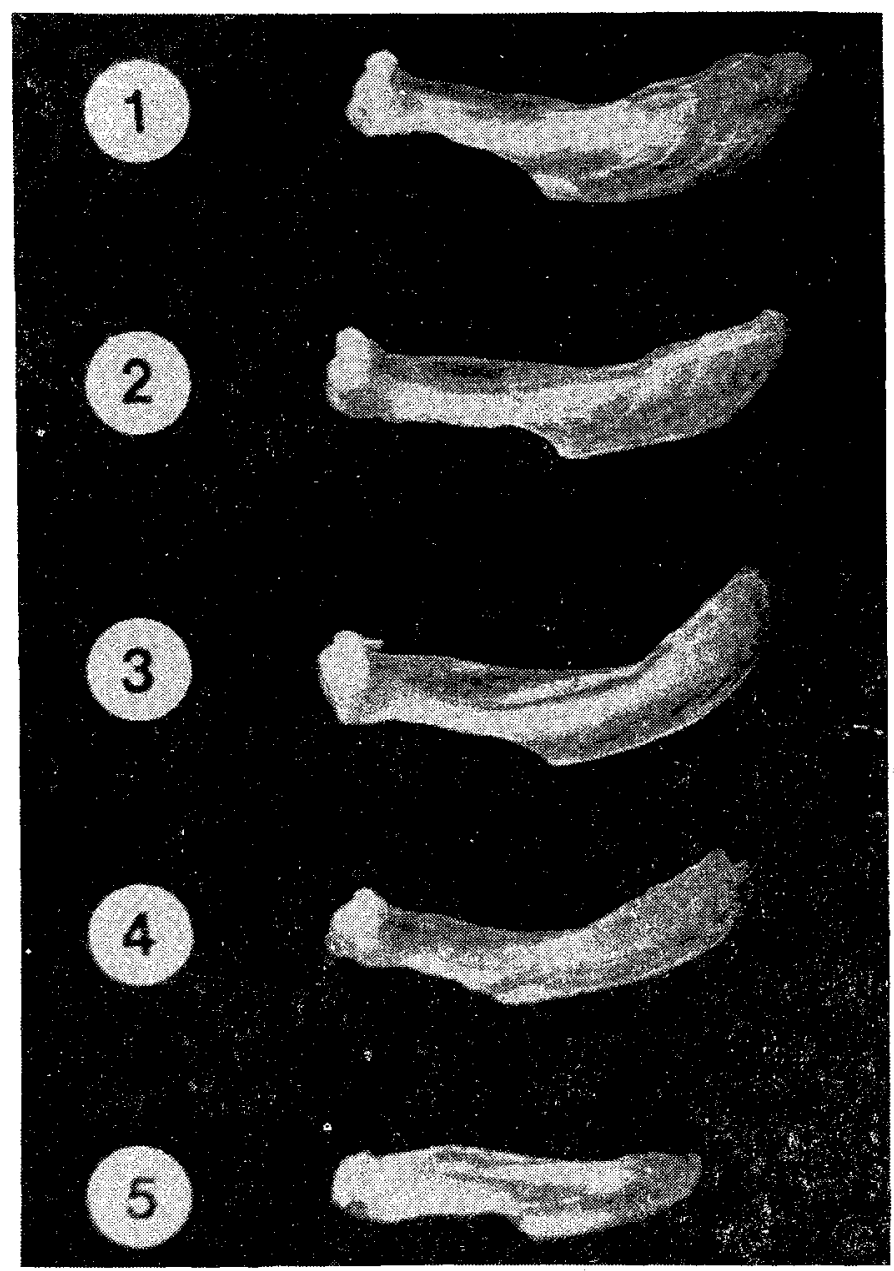

Fig. 11. Different shapes of the maxilla 


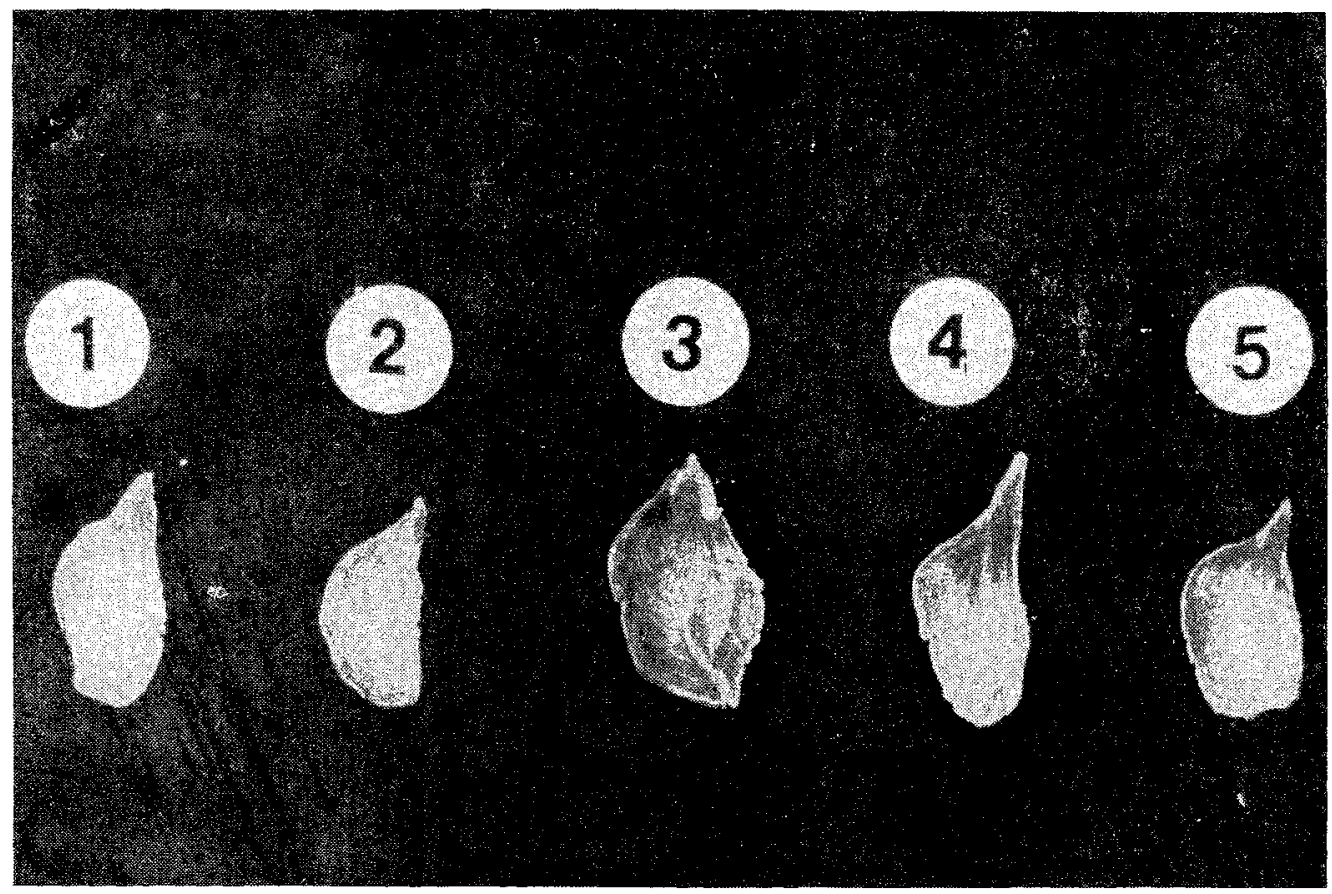

Fig. 12. Different shapes of the supramaxilla

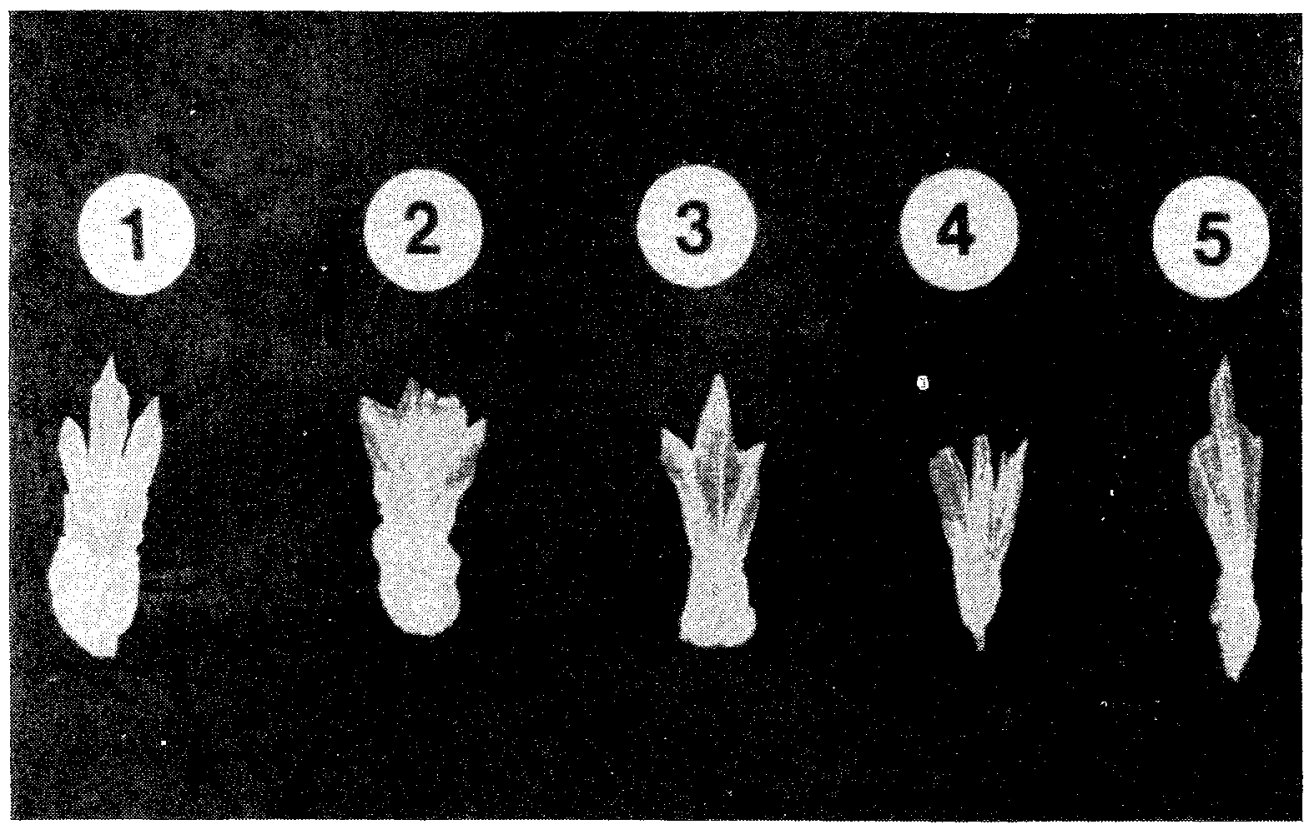

Fig. 13. Different shapes of the mesethmoid 
Shapes of the following bones: maxilla, supramaxilla, mesethmoid, and posttemporal are extremely variable and not always can be described by measurements or proportions. The maxillae presented in Fig. 11 are either arch-like curved or entirely straight. Their distal length is usually clearly longer than the proximal, but sometimes the two lengths are equal. Fig. 12 shows examples of the supramaxilla shapes ranging from strongly elongated and short to shortened in length and tall. The upper jaw of the whitefish additionally contains the premaxilla, in both forms covered with 5-8 fine teeth.

Exceptionally variable is the mesethmoid shape, the variability concerning width of the anterior plate and length of the shaft, thelatter forked in a variety of ways (Fig. 13).

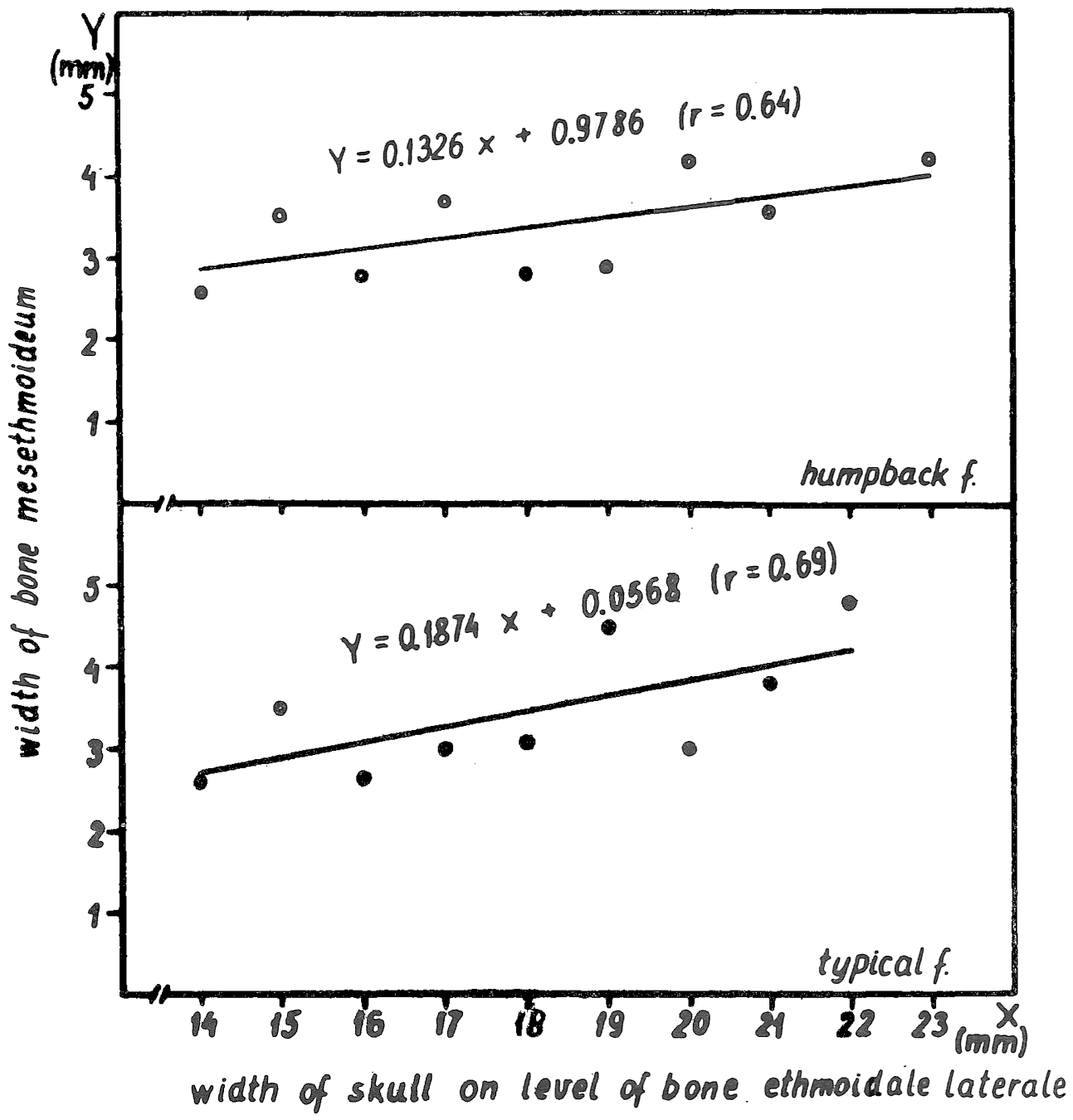

Fig. 14. Relationships between anterior plate of the mesethmoid.and cranial wid th at the lateral e thmoid level 
The anterior plate width depends on cranial width at the lateral ethmoid level (Fig. 14): the first increases with the other, the relationsjip holding for both forms but being more pronounced in the typical form.

The posttemporal is also very variable in shape, particularly in its lower part, strongly elongated and narrow or shovel-like flattened and short, connecting with the supracleithrum.

\section{DISCUSSION}

A comparison of the mean values calculated for the characters measured in the Pomeranian Bay whitefish with data reported by Šaposnnikova (1968) for a number of subspecies reveals that the population under study is closest to $C$. lavaretus ludoga Poljakov and C. lavaretus ssp. form the White Sea. Additionally, some characters are similar to those in C. lavaretus pidschian (Gmelin), C. lavaretus pallasi Pravdin, and C. lavaretus maraenoides Poljakov. It is only length of the frontal that differs the Pomeranian Bay whitefish from those studied by Šapošnikova (1968). In her cranial morphology-based identification key to the C. lavaretus subspecies, Sapošnikova described the mesethmoid anterior plate as very narrow in $C$. lavaretus lavaretus and wide in C. lavaretus baicalensis. Of the mesethmoids shown in Fig. 13, those with the widest anterior plates and short shafts resemble the description and drawing given by Saposnikova for $C$. lavaretus baicalensis.

It should be emphasised that all cranial parameters of the Pomeranian Bay whitefish are totally different from those of $C$. nasus (Pallas) occurring in the Northern Ocean and Alaskan drainages. Therefore Süärdson's (1957) introduction of $C$. nasus (Pallas) sensu Svärdson to identify the sparse gill raker whitefish of the Baltic Sea and its drainage does not seem justified. On the other hand, Himberg (1970) put forward another view. He considered $C$. nasus (Pallas) sensu Svärdson and $C$. pidschian ( $\mathrm{Gmelin}$ ) to be conspecifics. A typical Northern Ocean's $C$. pidschian differs fromothe Baltic forms in. i.a. shape and proportions of the maxilla (Gąsowska, 1960; Sapošnikova, 1968). Gąsowska (1960) regarded this character as very important and used it to elevate $C$. lavaretus pidschian (a subspecies according to Berg, 1948) to the species level as $C$. pidschion. On the other hand, Resetnikov (1980) failed to see firm justification for considering $\ddot{C}$. pidschian as a separate species. Biochemical assays and genetic stu dies (Lokšina, 1983; Kajdanova, 1983; and others) prove $C$. nasus to be the best defined coregonid species so far.

The high degree of polymorphism in meristic and plastic characters basically precludes adoption of any systematics proposed to date. The whitefish forms which developed identical phenotypes in European populations widely separated geographically can be regarded as members of a poly topic subspecies of the species Coregonus lavaretus (L.). As already known (Mayr, 1974a, b), such populations are not identical genetically. Because, however, a subspecies is not an evolu tionary concept, such visually identical populations can be lumped into a joint taxon of a subspecies rank. An altemative, according to Mayr 
(1974 a), is to give up separating the subspecies entirely. In view of a lack of diagnostic differences, any further subdivision of a polytopic subspecies into more subspecies differing only in their geographic location is hardly justified.

Based on the literature data, the already frequently quoted (Kaykorante and Mednikov, 1988) suggestion seems acceptable that the whitefish forms of the Baltic Sea drainage, Alps, and British Isles should be treated as Coregonus lavaretus (L., 1758) complex having a polytopic subspecies rank. The term "complex" is a neutral one and used informally (in terms of the Zoological Nomenclature Code); its usage becomes, however, in dispensable in unexplained cases. I also suggest that the already existing names of species and subspecies be retained but preceded by the term "forma". The latter term ought to be used when it is difficult to judge whether a phenone at hand is a valid species, a subspecies, or a manifestation of individual variability. For example, to follow the concept expressed above, the name Coregonus lavaretus generosus (Peters) should be substituted by Coregonus lavaretus forma generosus (Peters). One of the Alpine whitefish, Coregonus wartmanni (Bloch) should be renamed Coregonus lavaretus forma wartmanni (Bloch). To retain the original names with inclusion of the "forma" seems purposeful for practical, zoogeographic and sometimes also historical reasons.

\section{CONCLUSIONS}

1. Osteologic examinations did not confirm the separate nature of the two plastic forms (typical and humpback) of the whitefish.

2. The basic dimensions of the skull as well as its width and length measured in different places show a rela tively low variability.

3. Sahpes of maxilla, parietal, and mesethmoid are highly variable, which limits their taxonomic utility.

4. It seems necessary to collect data on cranial osteology of $C$. lavaretus from different geographic locations, based on representative sample sizes.

5. Both earlier works and the present study support the view that the whitefish of the Bal tic Sea drainage, Alps, and British Isles should be treated as a polytopic subspecies Coregonus lavaretus (L., 1758) complex. In view of a lack of diagnostic differences, division of a single polytopic subspecies into more subspecies differing in their geographic location is not justified.

\section{REFERENCĖS}

Behnke R., 1972: The sy stematics of salmonid fishes of recently glaciated lakes: J. Fish. Res. Bd. Can., 29, 6: 639-671.

Berg L.S., 1948: Ryby presnych vod SSSR i sopredelnych stran. Izd. AN SS̀SR, T. 1, Moskva (in Russian). 
Dorofejeva E.A., E.A. Zinovev, V.A., Kljukanov, Ju.S. ReY̌etnikov, K.A. Savvaitova, G.H. Sapoß̌nikova, 1980: Sovremennyje sostojanije issledovanij filogenii i klassifikacji lososevidnych ryb. Vopr. Ichtiol., 20, 5:771-791 (in Russian).

Gąsowska M., 1960: Genus Coregonus L. discussed in connection with a new systematic feature of shape and proportion of os maxillare and os supramaxillare. Ann. Zool., Warszawa, 18 (26): 471-513.

Heese T., 1987: Morphology of two plastic forms of whitefish, Coregonus lagaretus (L.) occurring in the Pomeranian Bay and Szczecin Lagoon. Acta Ich thyol. et Piscat., 17, 1:3-28.

Himberg K. - J.M., 1970: A systematic and zoogeographic study of some North European coregonids. In: Biology of Coregonid fishes. Winnipeg, Univ. Manitoba Press: 219-250.

Kajdanova T.J., 1983: Sravnitelnyj analiz piati vidov sigovych ryb. V kn.: Genetika promyslovych ryb i obiektov akvakultury. Izd. "Legkaja i piß̌̌evaja promyß̌lennost", Moskva: 25-28 (in Russian).

Kaykorante M., B.M. Mednikov, 1988: Genetið̌eskaja divergencja sigov Fennoskan dii. V. kn.: Biologija sigovycg ryb. Izd. "Nauka", Moskva: 31-48 (in Russian).

LokŠina A.B., 1983: Sravnitelnyj elektroforetiłeskij analiz nekotorych belkov sigovych ryb. V. kn.: Genetika promyslovych ryb i obiektov akvakultury. Izd. "Legkaja i piß̌̌evaja promyłlennost", Moskva: 19-24 (in Russian).

Mayr E., 1974a: Podstawy systematyki zwierząt. (Principles of systematic zoology). PWN, Warszawa (in Polish).

Mayr E., 1974b: Populacje, gatunki i ewolucja (Populations, Species, and Evolution). WP, Warszawa (in Polish).

Rešetnikov Ju.S., 1980: Ekologija i sitematika sigovych ryb. Izd. "Nauka", Moskva (in Russian).

Resetnikov Ju.S., 1988: Sovremennyj status sigovych ryb i perspektivy ispolzovanija ich zapasov. V kn.: Biologija sigovych ryb. Izd. "Nauka", Moskva: 5-17 (in Russian).

Šapošnikova G.H., 1968: Sravnitelno-morfologičeskoje opisanije sigov Sovetskogo Sojuza. Tr. Zool. in-ta AN SSSR, 46:207-256. (in Russian).

Svärdson G., 1957: The Coregonid problem. VI. The palearctic species and their intergrades. Rep. Inst. Freshwater Res. Drottningholm, 38: 267-356.

Svärdson G., 1979: Speciation of Scandinavian Corregonus. Rep. Inst. Freshwater Res. Drottningholm, 57: 3-95.

Translated: Dr. T. Radziejewska

\section{Tomasz Heese}

\section{OSTEOLOGIA CZASZKI SIEI, COREGONUS LAVARETUS (L., 1758) ZATOKI POMORSKIEJ}

\section{STRESZCZENIE}

Sieje do badań zostały złowione w listopadzie 1984 na Zatoce Pomorskiej w okolicach ujścia Świny. Na podstawie wcześniejszych badań morfologicznych pokroju ciała i cech merystycznych ustalono istnienie w tych wodach dwóch form plastycznych, typowej i wygrzbieconej.

Badania osteologiczne czaszki miały na celu porównanie jej budowy pomiędzy wróżnionymi formami i określenia zakresu zmienności analizowanych cech. Otrzymane, średnie dla poszczególnych cech obu form są praktycznie bardzo do siebie zbliżone. Widoczne różníce pojawiają się dla indeksu przedstawiającego wysokość dentale wyraz̊ną w \% długości tylnej tej kości. 
Badania osteologiczne nie potwierdziły jednoznaczne odrębności wyróżnionych form plastycznych. Podstawowe wymiary czaszki jak jej szerokość i wysokość mierzona w różnych miejscach charakteryzują się stosunkowo niską zmiennością. Wysoką zmienność kształtów obserwuje się dla zespołu kości szczękowych, kości ciemieniowych i kości sitowej środkowej (mesethmoideum) przez co przydatność ich dla celów taksonomicznych jest ograniczona.

Author's address:

Received: 1989.06 .22

Tomasz Heese

Zakład Biologii i Chemii Sanitarnej

Wyższa Szkoła Inżynierska

ul. Racławicka 15-17

75-620 Koszalin

Polska (Poland) 